\title{
Article \\ Contribution of Oxide Supports in Nickel-Based Catalytic Elimination of Greenhouse Gases and Generation of Syngas
}

\author{
Wasim Ullah Khan ${ }^{1, *(\mathbb{D}}$, Mohammad Rizwan Khan ${ }^{2} \mathbb{D}$, Rosa Busquets ${ }^{3} \mathbb{D}$ and Naushad Ahmad ${ }^{2}$ \\ 1 Chemical and Process Engineering, College of Engineering, University of Canterbury, \\ Christchurch 8041, New Zealand \\ 2 Department of Chemistry, College of Science, King Saud University, P.O. Box. 2454, \\ Riyadh 11451, Saudi Arabia; mrkhan@ksu.edu.sa (M.R.K.); anaushad@ksu.edu.sa (N.A.) \\ 3 School of Life Sciences, Pharmacy and Chemistry, Kingston University London, Penrhyn Road, \\ Kingston Upon Thames KTI 2EE, UK; r.busquets@kingston.ac.uk \\ * Correspondence: wasimkhan49@gmail.com
}

Citation: Khan, W.U.; Khan, M.R.; Busquets, R.; Ahmad, N.

Contribution of Oxide Supports in Nickel-Based Catalytic Elimination of Greenhouse Gases and Generation of Syngas. Energies 2021, 14, 7324

https://doi.org/10.3390/en14217324

Academic Editor: João Fernando Pereira Gomes

Received: 6 October 2021

Accepted: 1 November 2021

Published: 4 November 2021

Publisher's Note: MDPI stays neutral with regard to jurisdictional claims in published maps and institutional affiliations.

Copyright: (c) 2021 by the authors. Licensee MDPI, Basel, Switzerland. This article is an open access article distributed under the terms and conditions of the Creative Commons Attribution (CC BY) license (https:// creativecommons.org/licenses/by/ $4.0 /)$.

\begin{abstract}
Carbon dioxide and/or dry methane reforming serves as an effective pathway to mitigate these greenhouse gases. This work evaluates different oxide supports including alumina, Y-zeolite and H-ZSM-5 zeolite for the catalysis of dry reforming methane with Nickel (Ni). The composite catalysts were prepared by impregnating the supports with $\mathrm{Ni}(5 \%)$ and followed by calcination. The zeolite supported catalysts exhibited more reducibility and basicity compared to the alumina supported catalysts, this was assessed with temperature programmed reduction using hydrogen and desorption using carbon dioxide. The catalytic activity, in terms of $\mathrm{CH}_{4}$ conversion, indicated that $5 \mathrm{wt} \% \mathrm{Ni}$ supported on alumina exhibited higher $\mathrm{CH}_{4}$ conversion $(80.5 \%)$ than when supported on Y-zeolite (71.8\%) or H-ZSM-5 (78.5\%). In contrast, the H-ZSM-5 catalyst led to higher $\mathrm{CO}_{2}$ conversion $(87.3 \%)$ than Y-zeolite (68.4\%) and alumina (83.9\%) supported catalysts. The stability tests for $9 \mathrm{~h}$ time-on-stream showed that Ni supported with H-ZSM-5 had less deactivation (just $2 \%$ ) due to carbon deposition. The characterization of spent catalysts using temperature programmed oxidation $\left(\mathrm{O}_{2}\right.$-TPO), X-ray diffraction (XRD) and thermo-gravimetric analysis (TGA) revealed that carbon deposition was a main cause of deactivation and that it occurred in the lowest degree on the $\mathrm{Ni}$ H-ZSM-5 catalyst.
\end{abstract}

Keywords: $\mathrm{CO}_{2} ; \mathrm{CH}_{4}$; stability; H-ZSM-5; carbon deposition; greenhouse gas reduction

\section{Introduction}

Carbon dioxide $\left(\mathrm{CO}_{2}\right)$ and methane $\left(\mathrm{CH}_{4}\right)$ contribute to the increasing of the Earth's temperature. A reaction that can reduce the concentration of these gases is the dry reforming of methane, DRM (Equation (1)); this reaction can be very beneficial for the environment.

$$
\mathrm{CH}_{4}+\mathrm{CO}_{2} \rightarrow 2 \mathrm{CO}+2 \mathrm{H}_{2}, \Delta \mathrm{H}^{\circ}=247.3 \mathrm{~kJ} \mathrm{~mol}^{-1}
$$

In addition to the possible use of DRM for mitigating greenhouse gases involved in global warming, it can generate sustainable hydrogen and syngas $\left(\mathrm{CO}+\mathrm{H}_{2}\right)$. Syngas can be used as fuel and to produce a wide range of chemicals including methanol and hydrocarbons to make synthetic fuel [1]. DRM is of scientific and commercial importance [2,3].

Noble metal and base metal catalysts have been proposed for DRM [1]. Nickelbased metal catalysts have the potential to compete with noble metal-based catalysts when comparing their catalytic performance, cost, and abundance of the raw materials [2]. However, the existence of side reactions such as carbon monoxide disproportionation and methane decomposition brings challenge of coping with the deactivation of $\mathrm{Ni}$ catalysis due to coke deposits [2-4]. These are more problematic in DRM than in processes that include steam [4]. Moreover, sintering of metal particles also plays a role in decreasing the 
catalytic activity due to reducing the exposed active metal surface area. The improvement in catalytic activity performance and resistance to carbon deposition in $\mathrm{Ni}$ catalysis can be achieved by employing various preparation strategies leading to favorable structures (for instance, by adding promoters [5-9], selecting a suitable support which is usually a metal oxide [10-13], optimizing metal loading or using bimetallic active sites [3]). Among these strategies to reduce carbonaceous deactivation of the catalyst, catalyst supports offer advantages such as the possibility of dispersing metal catalyst nanoparticles over their surface. This enhances resistance to carbon deposition and can improve their catalytic activity [14]. The 3D network in zeolite supports, formed by shared oxygen atoms of $\mathrm{SiO}_{4}$ and $\mathrm{AlO}_{4}$ tetrahedra, possess high resistance to temperature and mechanical stability due to their ordered framework. Moreover, zeolites offer crystalline features such as uniform microporosity (diameter $<2 \mathrm{~nm}$ ), and pore shape that gives selectivity by controlling the entrance and exit of reactant molecules in zeolite channels [15-18]. The unique shape selectivity feature of zeolites lies behind their application as catalysts and adsorbents in various industries $[19,20]$. Moreover, suitable properties of zeolites including their high specific surface areas, well-defined microporous structure, high thermal stability and high capacity of $\mathrm{CO}_{2}$ adsorption [21,22] can play a role in catalysis. In addition, their potential in offering high metal dispersion, superior resistance to carbon formation, and suitable metal-support interaction has also attracted scientists towards utilizing zeolites as catalyst supports in the DRM reaction. Ni based catalysts supported on different zeolites have been reported for DRM reaction [23-29]. Hambali et al. [29] synthesized mesoporous fibrous MFI support via the microemulsion method and deposited Ni over support surfaces using double solvent, wetness impregnation, and physical mixing methods. The catalytic activity results revealed that $\mathrm{Ni}$ based catalysts prepared by wetness impregnation exhibited stable performance with least carbon deposition as compared with catalysts synthesized by double solvent or physical mixing approaches. It was found that the acidity of the support hindered the side reaction i.e., methane cracking mainly responsible for carbon deposition at high reaction temperatures $\left(800^{\circ} \mathrm{C}\right)$.

Keeping in mind the distinct properties of zeolites, this work fills the literature gap by providing an insight into the role of reducibility, carbon dioxide adsorption capacity, and basicity of zeolites in displaying stable performance during DRM. Furthermore, the aim of this research is to identify a conventional support that can enhance DRM, determine how zeolite supports can affect the DRM reaction, and determine how their stability and performance compares with conventional alumina supported Ni catalysts.

\section{Materials and Methods}

\subsection{Catalyst Synthesis}

In order to synthesize $5 \mathrm{wt} \%$ nickel-based catalysts, nitrate salt precursor $\left[\left(\mathrm{Ni}\left(\mathrm{NO}_{3}\right)_{2} \cdot 6 \mathrm{H}_{2} \mathrm{O}\right)\right]$ was wet impregnated over different supports including Y-zeolite $(\mathrm{Y}), \mathrm{H}-\mathrm{ZSM}-5(\mathrm{H})$ and alumina (A) to synthesize catalysts denoted as NY, NH, and NA, where $\mathrm{N}$ represents $5 \mathrm{wt} \% \mathrm{Ni}$ and $\mathrm{Y}$, and $\mathrm{H}$ and A represent respective supports. Briefly, $30 \mathrm{~mL}$ of $28 \mathrm{mM}$ of nickel precursor solution were added dropwise to a suspension of the individual oxide supports $(33 \mathrm{~g} / \mathrm{L})$ in deionized water stirred with magnetic bar at $300 \mathrm{rpm}$. This process was carried out at $60^{\circ} \mathrm{C}$. The catalysts were subsequently dried overnight $(12 \mathrm{~h})$ at $110{ }^{\circ} \mathrm{C}$ under atmospheric before being subjected to calcination at $500^{\circ} \mathrm{C}$ in MTI ${ }^{\circledR \circledR}$ furnace for $3 \mathrm{~h}$ under air atmosphere. The catalyst preparation steps and DRM over catalyst surface are pictorially depicted in Scheme 1. 


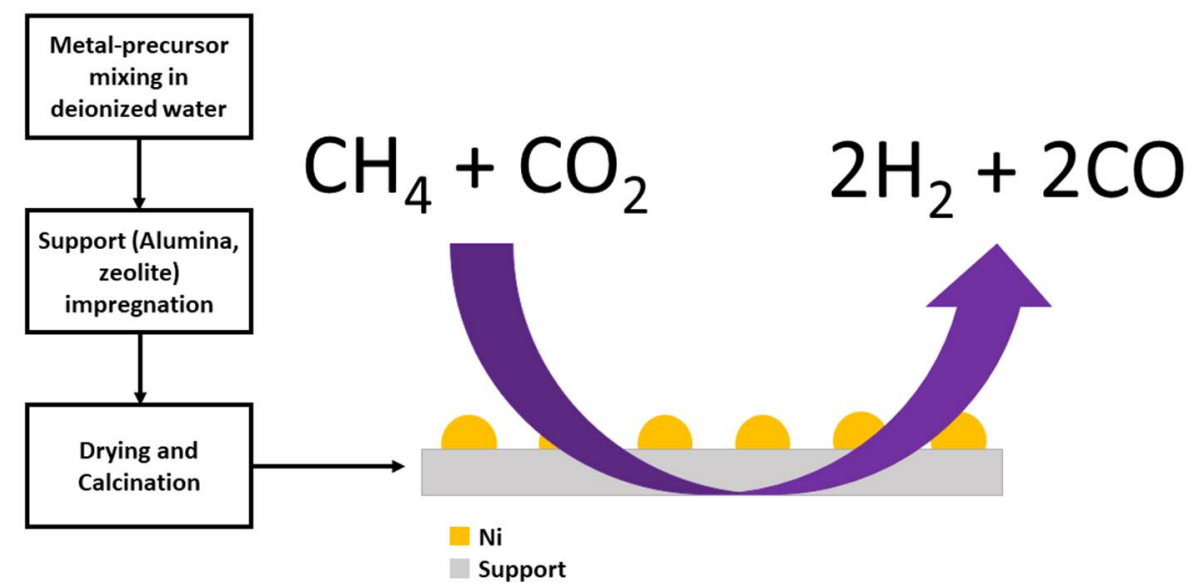

Scheme 1. Catalyst preparation steps and depiction of reforming reaction over catalyst.

\subsection{Catalytic Testing}

Catalytic activity tests for dry reforming reaction were carried out in a $10 \mathrm{~mm}$ i.d. and $40 \mathrm{~cm}$ long stainless steel-tube at atmospheric pressure using $600 \mathrm{mg}$ of a catalyst sample. Prior to the reaction, hydrogen gas $(40 \mathrm{~mL} / \mathrm{min})$ was used to activate the catalyst and to reduce the nickel oxide at $550{ }^{\circ} \mathrm{C}$ for $90 \mathrm{~min}$. Nitrogen was flown through the reactor to purge hydrogen and to cool down the reactor to the target reaction temperature. The feed gas had volume ratio of $17 / 17 / 2$ corresponding to methane/carbon dioxide/nitrogen mixture with total feed flow rate of $36 \mathrm{~mL} / \mathrm{min}$. The products and unconverted reactants were monitored by an online gas chromatograph (SRI Instruments) equipped with a flame ionization detector (FID) and a thermal conductivity detector (TCD).

\subsection{Catalyst Characterization}

BET specific surface area measurements were conducted on a Micromeritics Physisorption Unit (Gemini VI) by using a $300 \mathrm{mg}$ sample. All of the samples were pre-treated before analysis to remove any impurities and subsequently analyzed under a liquid nitrogen atmosphere. X-ray diffraction (XRD) analysis of powder samples were carried out using a Rigaku (Miniflex) diffractometer equipped with radiation source of $\mathrm{Cu} \mathrm{K} \alpha$ radiation which was operated at $40 \mathrm{kV}$ and $40 \mathrm{~mA}$. Temperature-programmed characterizations including desorption (TPD), reduction (TPR), and oxidation (TPO) were conducted using chemisorption apparatus (Micromeritics Auto Chem II apparatus). For $\mathrm{H}_{2}$-TPR, pretreatment of $50 \mathrm{mg}$ of the catalyst sample was carried out under Argon (Ar) flowing at $20 \mathrm{~mL} / \mathrm{min}$ at $150{ }^{\circ} \mathrm{C}$ for $30 \mathrm{~min}$. Then, the sample was cooled down to room temperature before the temperature was raised to $1000{ }^{\circ} \mathrm{C}$ using a furnace and temperature ramp rate of $10^{\circ} \mathrm{C} / \mathrm{min}$ under mixture of $10 \% \mathrm{H}_{2}$ in Ar flowing at $40 \mathrm{~mL} / \mathrm{min}$. For $\mathrm{CO}_{2}-\mathrm{TPD}$ measurements, same amount of sample (50 mg) was pretreated at $200{ }^{\circ} \mathrm{C}$ under helium (He) flowing at $20 \mathrm{~mL} / \mathrm{min}$ for $1 \mathrm{~h}$ followed by cooling the sample down to $50{ }^{\circ} \mathrm{C}$ at which $\mathrm{CO}_{2}$ was adsorbed for $30 \mathrm{~min}$ by flowing mixture of $10 \% \mathrm{CO}_{2}$ in helium at $30 \mathrm{~m} / \mathrm{min}$. The desorption profiles were recorded using thermal conductivity detector (TCD) by raising temperature linearly from 60 to $800{ }^{\circ} \mathrm{C}$ using $10^{\circ} \mathrm{C} / \mathrm{min}$. Carbon deposition and type of graphitic carbon were analyzed using TPO experiments in which catalyst samples were pretreated at $150{ }^{\circ} \mathrm{C}$ for $30 \mathrm{~min}$ under helium flowing at $30 \mathrm{~mL} / \mathrm{min}$ followed by cooling the samples down to room temperature. The oxidation profiles were measured by raising the sample temperature to $1000{ }^{\circ} \mathrm{C}$ using $10{ }^{\circ} \mathrm{C} / \mathrm{min}$ under mixture of $10 \% \mathrm{O}_{2}$ in helium flowing at $30 \mathrm{~mL} / \mathrm{min}$. The weight loss of the spent catalysts samples was analyzed using the thermogravimetric analysis (TGA) where $20 \mathrm{mg}$ of each sample was subjected to heating under air from room temperature to $800{ }^{\circ} \mathrm{C}$ using $10^{\circ} \mathrm{C} / \mathrm{min}$. 


\section{Results}

\subsection{Catalytic Activity}

$5 \mathrm{wt} \% \mathrm{Ni}$ supported over $\gamma-\mathrm{Al}_{2} \mathrm{O}_{3}, \mathrm{Y}$-zeolite and $\mathrm{H}-\mathrm{ZSM}-5$ catalysts (for simplification, these catalysts are designated as NA, NY and $\mathrm{NH}$, respectively) were studied for DRM reaction at different temperatures from 500 to $700{ }^{\circ} \mathrm{C}$. Figure $1 \mathrm{a}, \mathrm{b}$ shows activity performance in terms of $\mathrm{CH}_{4}$ conversion and $\mathrm{H}_{2} / \mathrm{CO}$ ratios versus temperature for the $\mathrm{NA}, \mathrm{NY}$, and $\mathrm{NH}$ catalysts, respectively. The activity results demonstrate an increase in $\mathrm{CH}_{4}$ conversion with increase in reaction temperature from 500 to $700{ }^{\circ} \mathrm{C}$ which confirms the endothermic nature of DRM reaction $[30,31]$. The ratios of $\mathrm{H}_{2}$ to $\mathrm{CO}$ show interesting trends for each catalyst. It is noteworthy that $\mathrm{CH}_{4}$ conversion is mainly responsible for $\mathrm{H}_{2}$ production while $\mathrm{CO}$ comes from $\mathrm{CO}_{2}$. Hence, $\mathrm{H}_{2} / \mathrm{CO}$ ratios less than unity clearly justifies $\mathrm{CO}_{2}$ conversions are higher than $\mathrm{CH}_{4}$ conversion and vice versa. $\mathrm{CO}_{2}$ conversions higher than $\mathrm{CH}_{4}$ conversions also proves the occurrence of reverse water gas shift reaction $\left(\mathrm{CO}_{2}+\mathrm{H}_{2} \leftrightarrow \mathrm{CO}+\mathrm{H}_{2} \mathrm{O}\right)$ which consumes $\mathrm{H}_{2}$ and brings $\mathrm{H}_{2} / \mathrm{CO}$ ratios less than one. This also suggests that $\mathrm{H}_{2} / \mathrm{CO}$ ratios higher than one, resulting from higher $\mathrm{CH}_{4}$ conversions, lead to the catalysts being more prone to carbon deposition [31].
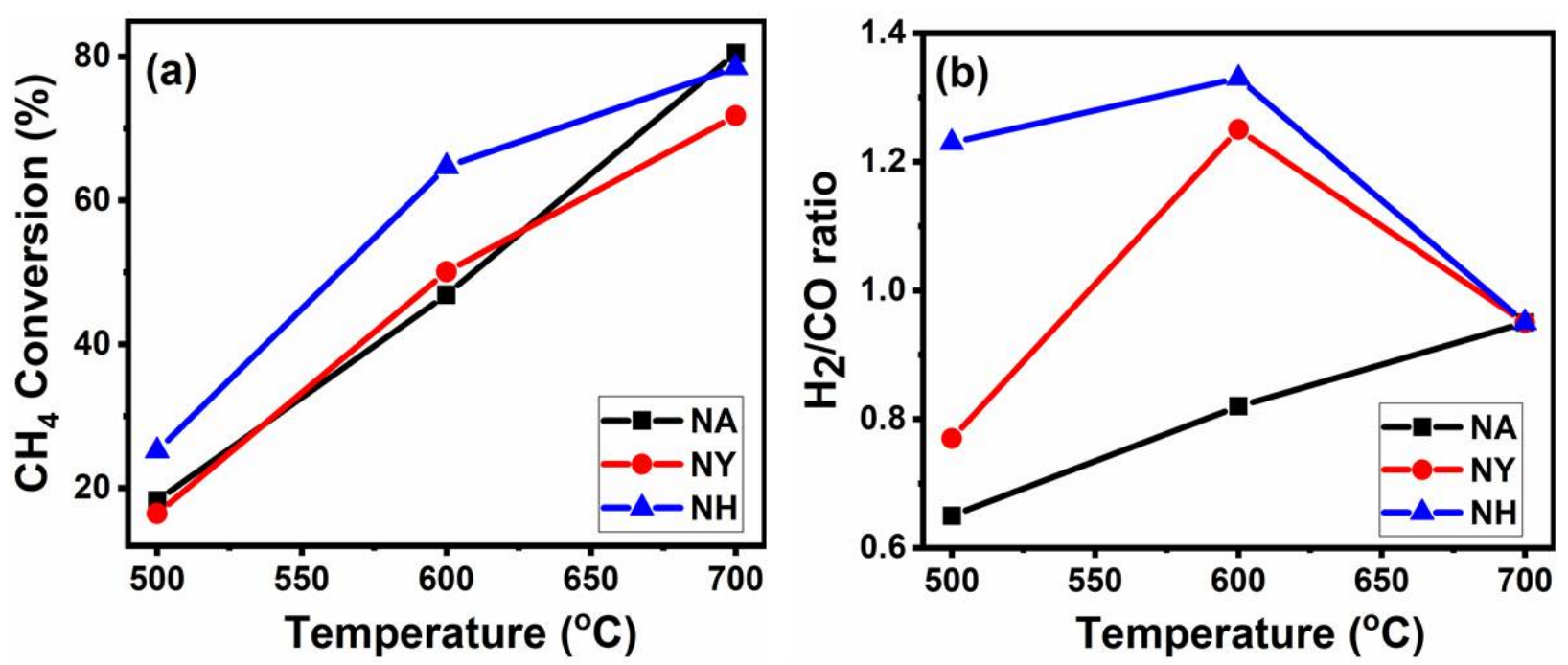

Figure 1. (a) $\mathrm{CH}_{4}$ and (b) $\mathrm{CO}_{2}$ conversion versus time on stream for $\mathrm{Ni}$ supported on alumina (NA), Ni supported on Y-zeolite (NY), and Ni supported on H-ZSM-5 (NH) catalysts.

\subsection{Catalytic Stability}

The deposition of carbon over the surface of a catalyst is crucial to investigate in examining DRM reactions. The stability of a catalyst is evaluated by testing its activity for a prolonged time to estimate the loss in activity. Figure 2 presents $\mathrm{CH}_{4}$ and $\mathrm{CO}_{2}$ conversions as a function of time for $9 \mathrm{~h}$ time on stream at fixed reaction temperature of $700{ }^{\circ} \mathrm{C}$. The decrease in both $\mathrm{CH}_{4}$ and $\mathrm{CO}_{2}$ conversions was obvious for all of the tested catalysts (NA, $\mathrm{NY}$ and $\mathrm{NH}$ ) and it was associated with the deactivation of all the catalysts. Interestingly despite that all catalysts showed deactivation, the extent of deactivation was not the same for all the catalysts. From quantitative results in Table 1, the NH catalyst showed negligible loss in $\mathrm{CH}_{4}$ and $\mathrm{CO}_{2}$ conversions as compared with $\mathrm{NA}$ (2.3 and $5.2 \%$ respectively) and NY (5 and $1.1 \%$ respectively) catalysts. The deactivation factor as function of extent of deactivation or catalyst stability was found to be the lowest $(2 \%)$ in the $\mathrm{NH}$ catalyst. 

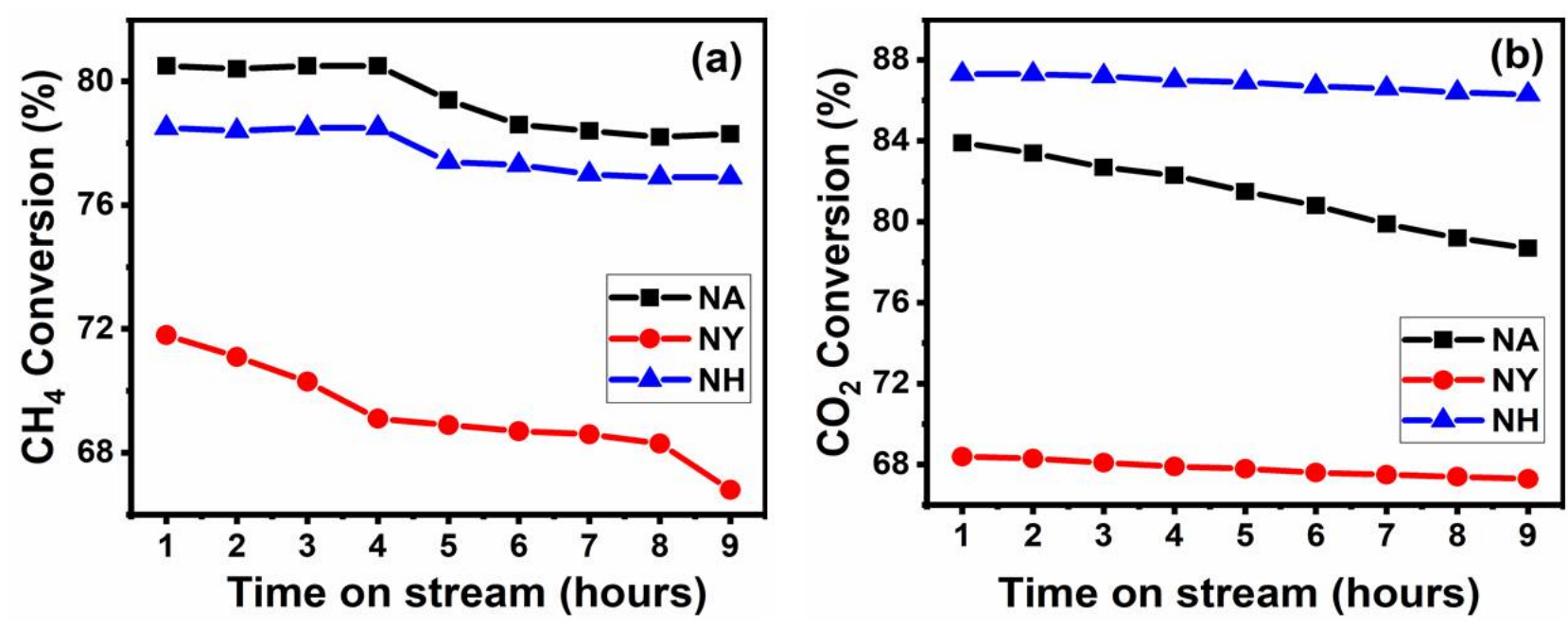

Figure 2. (a) $\mathrm{CH}_{4}$ and (b) $\mathrm{CO}_{2}$ conversion versus time on stream for $\mathrm{Ni}$ supported on alumina (NA), Ni supported on Y-zeolite (NY), and Ni supported on H-ZSM-5 (NH) catalysts.

Table 1. Performance of NA, NY, and NH catalysts in $\mathrm{CO}_{2}$ reforming of methane after $9 \mathrm{~h}$.

\begin{tabular}{|c|c|c|c|c|}
\hline Catalyst & $\% \mathrm{DF}^{\mathrm{a}}$ & Coke (wt. \%) ${ }^{b}$ & $S_{\text {BET }}\left(m^{2} / g\right)^{c}$ & $S_{\text {BET }}\left(\mathrm{m}^{2} / g\right)^{d}$ \\
\hline $\mathrm{NH}$ & 2.0 & 3.7 & 335.3 & 318.4 \\
\hline NY & 6.9 & 14.7 & 573.3 & 498.1 \\
\hline NA & 2.9 & 8.5 & 209.7 & 171.7 \\
\hline
\end{tabular}

$\overline{{ }^{a} \text { Deactivation Factor }(\% \mathrm{DF})=\left[\left(\left[\mathrm{CH}_{4}\right]_{\text {initial }}-\left[\mathrm{CH}_{4}\right]_{\text {final }}\right) /\left[\mathrm{CH}_{4}\right]_{\text {initial }}\right] \times 100 ;{ }^{\mathrm{b}} \text { Determined by TGA; }{ }^{\mathrm{c}} \text { Before }}$ reaction; ${ }^{\mathrm{d}}$ After reaction.

Thermodynamically two of the side reactions including methane decomposition and Boudouard reaction (Equation (2)) are mainly forming carbon over the catalyst surface under reaction conditions [30].

$$
2 \mathrm{CO} \rightleftharpoons \mathrm{CO}_{2}+\mathrm{C}
$$

In order to investigate whether carbon formation was the main source of deactivation, thermogravimetric analysis (TGA) was used to quantify the carbon deposition. It can be clearly seen from TGA results in Table 1 that the NH catalyst exhibited weight loss of $3.7 \mathrm{wt} \%$ much lesser than NY $(14.7 \mathrm{wt} \%)$ and NA $(8.5 \mathrm{wt} \%)$. Hence, it can be concluded that the $\mathrm{NH}$ catalyst proves to show long term stability and lowest amount of carbon deposition. These findings are further discussed based on the characterizations of the catalysts before and after reaction as described in the following paragraphs.

The stability of the best catalyst $(\mathrm{NH})$ in the current study is compared with the catalysts supported on zeolite or oxide supports (Table 2) and deactivation factor was used as a measure of stability. The deactivation factor over 5\%Ni-ZSM [32] catalyst for similar reaction duration of $9 \mathrm{~h}$ was much higher $(24.2 \%)$ than the $\mathrm{NH}$ catalyst $(2 \%)$. Even $\mathrm{Ni}$ and Co based bimetallic catalyst supported on ZSM5 (1Co2Ni-ZSM5) [28] showed deactivation factor over 6 times higher $(13.6 \%)$ than the $\mathrm{NH}$ catalyst. These catalysts were even tested at higher temperature $\left(800{ }^{\circ} \mathrm{C}\right)$ as compared with the current $\mathrm{NH}$ catalyst (tested at $\left.700{ }^{\circ} \mathrm{C}\right)$. Comparing the $\mathrm{NH}$ catalyst with alumina $\left(2.25 \% \mathrm{Sr}-10 \% \mathrm{Co} / \mathrm{Al}_{2} \mathrm{O}_{3}\right)$ [33], ceria (Ni-Ce Imp) [34], and MCM41 [35] supported catalysts, the later catalysts showed more deactivation even with shorter reaction duration. Hence it can be concluded that the $\mathrm{NH}$ catalyst presents potentially more stable performance than other zeolite supported catalysts as well as catalysts with higher metal contents or employed promoters. 
Table 2. Comparison of current work with the previously reported work.

\begin{tabular}{|c|c|c|c|c|c|}
\hline Catalyst & Reaction Temp. $\left({ }^{\circ} \mathrm{C}\right)$ & $\begin{array}{c}\text { Initial } \mathrm{CH}_{4} \\
\text { Conversion (\%) }\end{array}$ & $\% \mathrm{DF}$ & TOS (h) & Ref. \\
\hline $7 \% \mathrm{Ni} / \mathrm{ZSM}-5$ & 700 & 91 & 35.3 & 5 & \multirow{2}{*}[14]{} \\
\hline 7\% Ni/ Zeolite Y & 700 & 92 & 0.43 & 5 & \\
\hline 1Co2Ni-ZSM5 & 800 & 66 & 13.6 & 12 & [28] \\
\hline $5 \% \mathrm{Ni}-\mathrm{ZSM}$ & 800 & 96.2 & 24.2 & 9 & [32] \\
\hline $2.25 \% \mathrm{Sr}-10 \% \mathrm{Co} / \mathrm{Al}_{2} \mathrm{O}_{3}$ & 700 & 80.1 & 2.5 & 6 & [33] \\
\hline Ni-Ce Imp & 700 & 81.1 & 3.7 & 6 & [34] \\
\hline $5 \% \mathrm{Ni}+1 \% \mathrm{Sc} / \mathrm{MCM} 41$ & 800 & 65 & 19.2 & $\sim 7$ & {$[35]$} \\
\hline $\mathrm{NH}$ & 700 & 78.5 & 2.0 & 9 & This work \\
\hline
\end{tabular}

\subsection{Catalysts Characterization}

The specific surface areas measured by Brunauer-Emmett-Teller (BET) isotherms of all of the catalysts before and after DRM reaction are given in Table 1. The NY catalyst is found to have highest specific surface area $\left(573.3 \mathrm{~m}^{2} / \mathrm{g}\right)$ before reaction but NY catalyst also showed significant loss (13\%) in specific surface area during reaction. The NA catalyst showed a loss of $18 \%$ in specific surface area while $\mathrm{NH}$ catalyst exhibited a minimum loss of $5 \%$. The loss in specific surface area is accounted for carbon formation over the catalyst surface during DRM reaction. The minimal loss in specific surface area for $\mathrm{NH}$ catalyst indicates its superior stability under reaction conditions.

In order to estimate the crystallinity and different phases of the as-synthesized catalysts, X-ray diffraction (XRD) study was conducted over NA, NY and NH fresh catalysts and NA used catalyst. From Figure 3, the characteristic peaks of $\mathrm{NiO}$ were found over all the catalysts at two theta values of 44 and $63^{\circ}$ (JCPDS: 01-073-1519), except for the fact that $\mathrm{NY}$ and $\mathrm{NH}$ catalysts showed additional peak of $\mathrm{NiO}$ at $37^{\circ}$ (JCPDS: 01-073-1519). The peaks at 42 and $66^{\circ}$ in the case of NA catalysts are characteristics of alumina support (JCPDS: 00-004-0875). The diffraction peaks had higher intensities in case of NY and NH catalysts as compared with NA catalyst showing higher crystallinity of the former catalysts. The NA catalyst after reaction revealed the formation of carbon during reaction as indicated by strong diffraction peak at $26^{\circ}$ associated with graphite. Moreover, in addition to $\mathrm{Ni}^{0}$, the NA catalyst after reaction also showed a characteristic peak of spinel $\mathrm{NiAl}_{2} \mathrm{O}_{4}$ (JCPDS: 01-073-0239) at 45 and $78^{\circ}$.

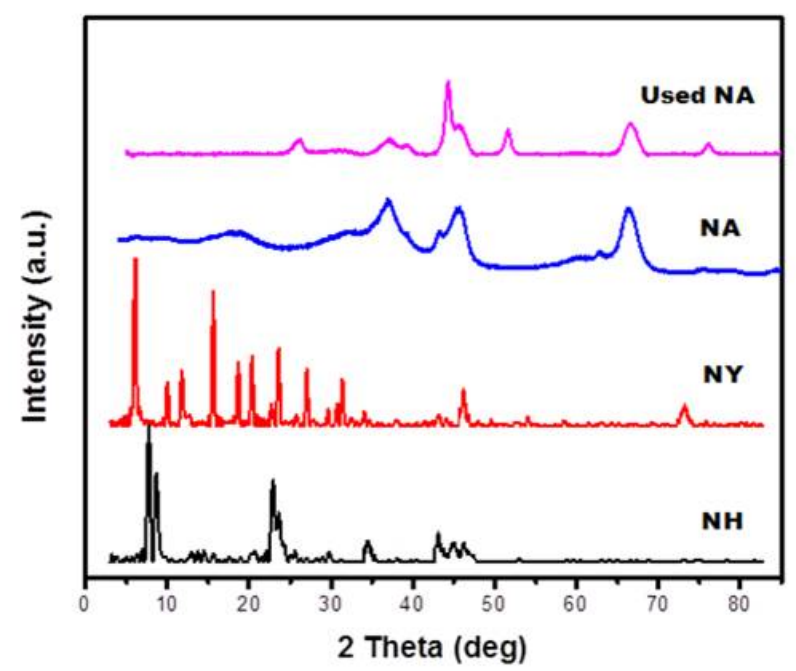

Figure 3. XRD patterns for Ni supported on alumina (NA), Ni supported on Y-zeolite (NY), and Ni supported on H-ZSM-5 (NH) fresh and Ni supported on alumina (NA) used catalysts. 
The temperature-programmed oxidation (TPO) is a useful technique to estimate the amount of carbon formed during reaction by oxidizing the carbon as function of temperature. TPO also provides significant details about the structure, morphology and composition of accumulated carbon. Figure 4 displays the TPO profiles as a function of temperature for all the three catalysts (NA, NY and NH respectively). The spent or used catalysts exhibited carbon gasification peaks in the temperature range from 400 to $640{ }^{\circ} \mathrm{C}$ associated with different types of carbon including carbon nanofibers and carbon nanotubes.

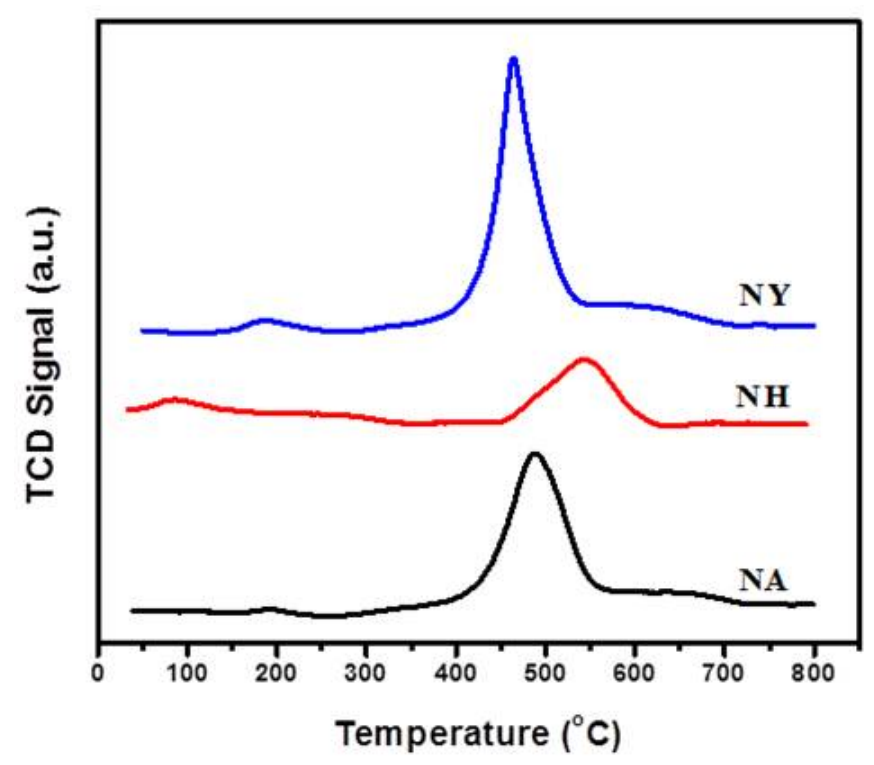

Figure 4. TPO profiles for Ni supported on alumina (NA), Ni supported on Y-zeolite (NY), and Ni supported on H-ZSM-5 (NH) spent catalysts.

The following four side reactions are most probably responsible for carbon deposition during DRM reaction.

$$
\begin{gathered}
2 \mathrm{CO} \leftrightarrow \mathrm{CO}_{2}+\mathrm{C} \\
\mathrm{CH}_{4} \leftrightarrow 2 \mathrm{H}_{2}+\mathrm{C} \\
\mathrm{CO}+\mathrm{H}_{2} \leftrightarrow \mathrm{H}_{2} \mathrm{O}+\mathrm{C} \\
\mathrm{CO}_{2}+2 \mathrm{H}_{2} \leftrightarrow 2 \mathrm{H}_{2} \mathrm{O}+\mathrm{C}
\end{gathered}
$$

As mentioned earlier, the first two reactions are favorable at high temperatures while the last two reactions (reactions (5) and (6)) require lower temperatures [36]. The peak temperature indicates the type of carbon formed, and hence it is obvious that the carbon formed over the surface of NY (corresponding peak temperature of $\sim 460{ }^{\circ} \mathrm{C}$ ) and NY (corresponding peak temperature of $\sim 490{ }^{\circ} \mathrm{C}$ ) is less crystalline and easily gasified as compared with crystalline carbon deposited over the surface of $\mathrm{NH}$ catalyst (corresponding peak temperature of $\sim 545^{\circ} \mathrm{C}$ ). The peak intensity shows the amount of carbon formed, and it is obvious that NH catalyst had less amount of carbon deposition among all of the catalysts [37].

The extent of interaction between the metal and support plays a vital role in catalytic activity. Temperature-programmed reduction (TPR) using hydrogen is utilized to measure the metal-support interaction for NA, NY, and NH catalysts and extent of reducibility of each catalyst. Figure 5 shows the reduction profiles for NA, NY, and NH fresh catalysts as a function of temperature. NY catalyst exhibited two peaks at 350 and $440{ }^{\circ} \mathrm{C}$ along with a shoulder centered at $550{ }^{\circ} \mathrm{C}$. The two low temperature peaks are assigned to the reduction of $\mathrm{NiO}$ species weakly interacting with the support while shoulder is ascribed to the reduction of $\mathrm{NiO}$ species having medium interaction with the support (Y-zeolite). Also, 
the NY catalyst shows $\mathrm{NiO}$ species which are easier to reduce as compared with the NA and $\mathrm{NH}$ catalysts.

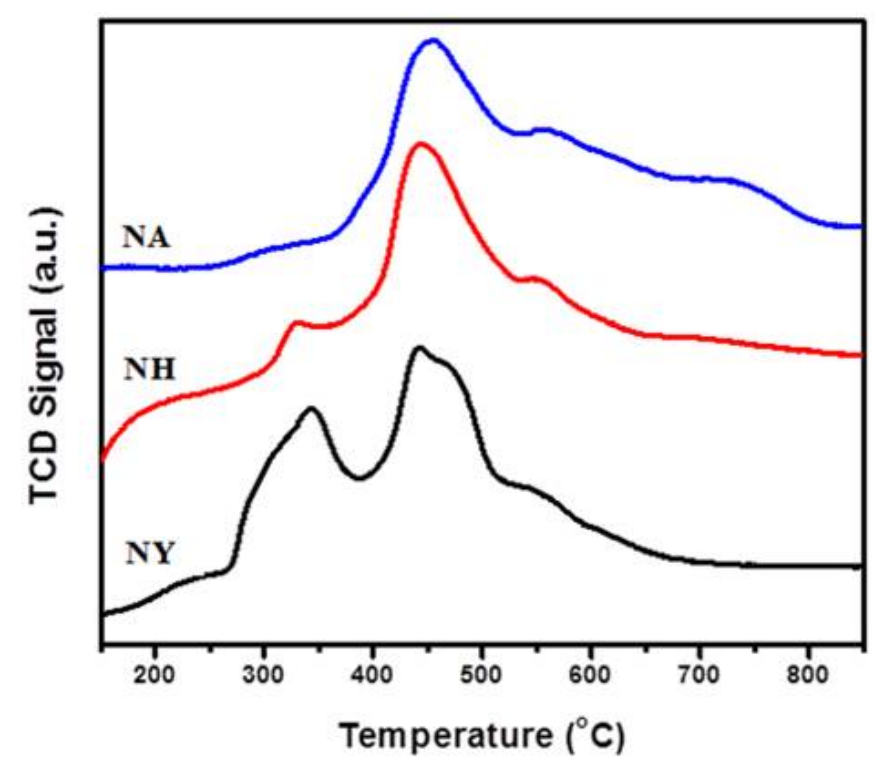

Figure 5. TPR profiles for Ni supported on alumina (NA), Ni supported on Y-zeolite (NY), and Ni supported on H-ZSM-5 (NH) fresh catalysts.

In case of $\mathrm{NH}$ catalyst, the first smaller peak is centered at $330{ }^{\circ} \mathrm{C}$ and a second large peak has maxima at $450{ }^{\circ} \mathrm{C}$ while the shoulder is centered at $560^{\circ} \mathrm{C}$. This suggests that the strength of $\mathrm{NiO}$ species over $\mathrm{NH}$ catalyst is not significantly different than the NY catalyst. On the contrary, NA catalyst gave only one distinct reduction peak at $455^{\circ} \mathrm{C}$ with two smaller shoulders centered at 560 and $740{ }^{\circ} \mathrm{C}$, respectively. It is interesting to note that lower temperature peak appearing in the $330-350{ }^{\circ} \mathrm{C}$ range is disappeared in NA catalyst while a new shoulder at $740^{\circ} \mathrm{C}$ is observed. These results suggest that NA catalyst showed medium to strong metal-support interactions. The shoulder at $740{ }^{\circ} \mathrm{C}$ is assigned to the reduction of spinel $\mathrm{NiAl}_{2} \mathrm{O}_{4}$ species.

The extent of basic sites and their strength for fresh NA, NY, and NH catalysts was measured by employing temperature-programmed desorption (TPD) using $\mathrm{CO}_{2}$. The basicity of the catalyst is found to influence the carbon deposition and a higher number of basic sites led to lesser amount of carbon deposition [38]. The enhanced basicity promotes $\mathrm{CO}_{2}$ activation over the surface of the catalyst which reacts with carbon formed due to side reactions. Consequently, reverse Boudouard reaction $\left(2 \mathrm{CO} \rightleftharpoons \mathrm{CO}_{2}+\mathrm{C}\right)$ converts the carbonaceous species into $\mathrm{CO}$. Hence, the catalyst with higher basicity is expected to show the minimum carbon deposition. $\mathrm{CO}_{2}$-TPD profiles are shown in Figure 6 for fresh NA, NY, and NH catalysts.

NA catalyst presents two peaks, centered at 80 and $260{ }^{\circ} \mathrm{C}$, along with a shoulder centered at $560{ }^{\circ} \mathrm{C}$. The two peaks which appeared at lower temperatures are associated with weak basic sites and the shoulder represents strong basic sites. In the case of the NY catalyst, a small peak appears at $150^{\circ} \mathrm{C}$ while a broad peak is centered at $275^{\circ} \mathrm{C}$ and both are assigned to weak basic sites. $\mathrm{NH}$ catalyst shows two peaks with peak maxima at 130 and $300{ }^{\circ} \mathrm{C}$ respectively along with a shoulder centered at $550{ }^{\circ} \mathrm{C}$. The first peak represents weak basic sites and the second peak is associated with medium basic sites while the shoulder is assigned to strong basic sites. It is noteworthy that the peaks for $\mathrm{NH}$ catalysts are broader than NY and NA catalysts and hence exhibit more amount of $\mathrm{CO}_{2}$ adsorbed which leads to lesser carbon formation. This is in agreement with the TGA and $\mathrm{TPO}$ results. 


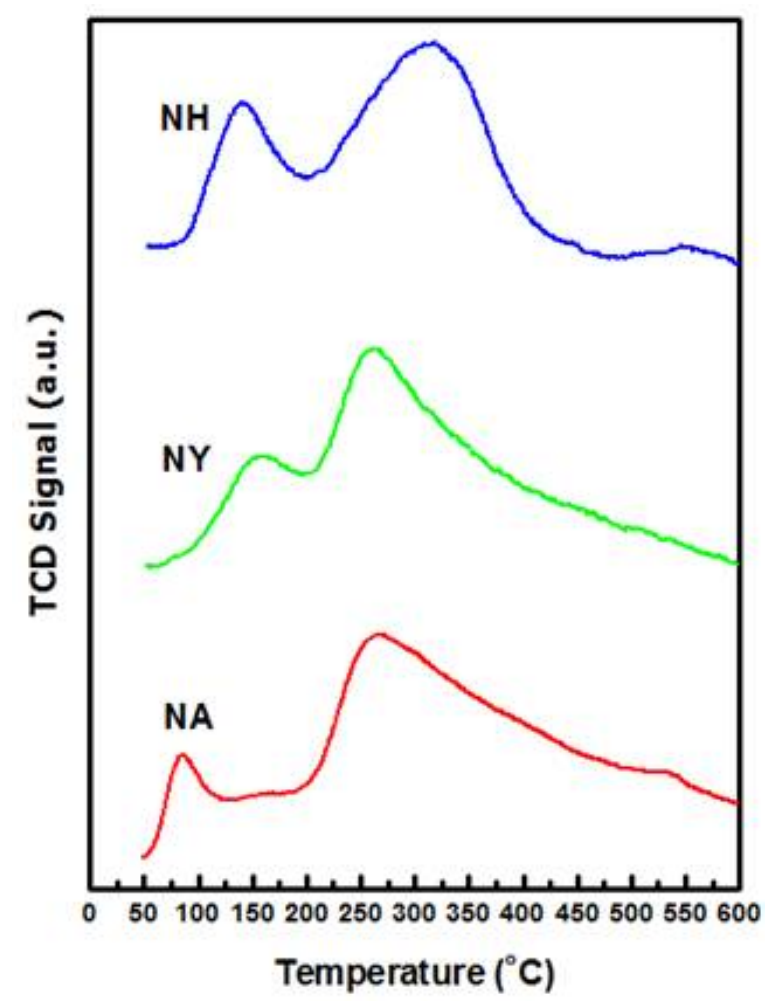

Figure 6. $\mathrm{CO}_{2}$-TPD for $\mathrm{Ni}$ supported on alumina (NA), Ni supported on Y-zeolite (NY), and $\mathrm{Ni}$ supported on H-ZSM-5 (NH) fresh catalysts.

\section{Discussion}

Prior to DRM reaction study, as-synthesized Ni based catalysts were characterized to assess their potential performance in the reforming reaction. High specific surface areas in zeolites are known to influence the catalytic performance during DRM [39]. It is noteworthy that despite the higher specific surface area of the study Y-zeolite, as compared with $\mathrm{H}$ ZSM-5 and alumina, the Y-zeolite supported Ni catalyst (NY) exhibited less conversions at lower reaction temperatures (Figure 1). This could be attributed to the zeolite having pores filled with nickel particles and/or the presence of nickel particles entrapped in the pores of zeolite and hence these were not available for DRM reaction [40]. Furthermore, the loss of specific surface area (Table 1) in the spent catalysts also demonstrates the drastic role of carbon deposition during DRM. The XRD diffraction profiles from the as-synthesized catalysts (Figure 3) have helped to identify crystalline phases (nickel oxide, alumina, and zeolites) in the composites. The presence of spinel species such as nickel aluminate was also obvious. Moreover, the deposition of crystalline graphitic carbon was further confirmed by XRD data of spent NA catalyst. The reduction profiles using TPR (Figure 5) demonstrate easier reduction of Ni oxides or higher reducibility of the Y-zeolite supported catalysts (NY) as compared to the alumina (NA) and H-ZSM-5 supported catalysts (NH). The basicity of the composites, assessed in terms of temperature programmed desorption data using carbon dioxide as probe gas, showed that the H-ZSM-5 supported catalyst $(\mathrm{NH})$ exhibited larger $\mathrm{CO}_{2}$ adsorption capacity than the rest of the study catalysts. The pre-reforming characterization results indicated larger specific surface area, higher number of reducible species and relatively lower basicity in the Y-zeolite supported catalyst (NY). These characteristics lead to expect better performance by NY during the reforming reaction however the activity results (Figures 1 and 2) did not follow the prediction. The DRM mechanism requires adsorption of reactants over the active sites of the catalyst in its initial step. Subsequently, they will react leading to products that ultimately will leave the catalyst surface following desorption [30]. $\mathrm{CH}_{4}$ adsorption requires $\mathrm{Ni}$ in its metallic form as the active site [40]. 
The catalytic stability (Figure 2) in terms of both $\mathrm{CH}_{4}$ and $\mathrm{CO}_{2}$ conversions showed loss of activity over time for all catalysts with varying deactivation degrees. The decrease in initial conversions for zeolite supported catalysts can be assigned to loss of Ni active sites residing inside the pores in the zeolite. The $\mathrm{CO}_{2}$ adsorption capacity is also found to influence the catalytic performance and hence more $\mathrm{CO}_{2}$ conversion is evidenced from $\mathrm{H}$ ZSM-5 supported catalyst $(\mathrm{NH})$ as compared to other catalysts in agreement with $\mathrm{CO}_{2}$-TPD results (Figure 6). Higher $\mathrm{CO}_{2}$ conversion helps to provide an oxidative environment to gasify carbon deposited over the surface of the catalyst and hence this can lead to less deactivation. Thus, the catalyst with the highest $\mathrm{CO}_{2}$ adsorption capacity and $\mathrm{CO}_{2}$ conversion i.e., H-ZSM-5 supported catalyst (NH), has shown to present the lowest deactivation factor: just $2 \%$. The main cause of deactivation was found to be carbon deposition according to TPO (Figure 4) and TGA (Table 1) results. The catalyst system studied in this work demonstrates the role of catalyst's properties such as reduction behavior, $\mathrm{CO}_{2}$ adsorption capacity and basicity of commercial zeolites in comparison with conventional alumina supported catalysts during DRM. A comprehensive study of the surface chemistry of the hierarchical zeolites using spectroscopic techniques and their performance evaluation in relation to commercial zeolites is planned.

\section{Conclusions}

The elimination of greenhouse gases via reforming $\mathrm{CH}_{4}$ with $\mathrm{CO}_{2}$, was investigated via heterogeneous catalysis. Specifically, the role of different supports (alumina and zeolites Y-zeolite and H-ZSM-5) for Ni-based catalysts were investigated for DRM. The activity results showed that Ni deposited onto H-ZSM-5 (NH catalyst) exhibited excellent stability (just $2 \%$ deactivation over $9 \mathrm{~h}$ on-stream) with the least amount of carbon deposition when compared with the Ni deposited onto alumina and Y-zeolite supports. The least amount of carbon deposition was confirmed with TGA and TPO. The favorable metal-support interaction and high basicity of Ni catalytic sites onto the H-ZSM- 5 contributed towards its stable performance. A comparison between the prepared NH catalyst with already reported catalysts for DRM reaction showed that the NH catalyst developed here, with $87.3 \%$ conversion of $\mathrm{CO}_{2}$, outperformed other $\mathrm{Ni}$ based catalysts and even bimetallic catalysts. The catalyst where $\mathrm{Ni}$ was deposited onto alumina showed the best conversion of $\mathrm{CH}_{4}(80.5 \%)$ compared to the zeolite supports, which led to up to $78.5 \% \mathrm{CH}_{4}$ conversion. Overall, Ni deposited onto H-ZSM-5 constitutes a catalyst with exceptional performance for the reduction of the greenhouse gases $\mathrm{CO}_{2}$ and $\mathrm{CH}_{4}$ (87.3 and $78.5 \%$ conversion, respectively) and generation of syngas. This study provides a platform to further evaluate the performance of hierarchical zeolites synthesized by modifying conventional zeolites.

Author Contributions: Conceptualization, W.U.K.; methodology, M.R.K. and N.A.; formal analysis, W.U.K.; writing—original draft preparation, W.U.K.; writing—review and editing, M.R.K., R.B. and N.A.; funding acquisition, M.R.K. All authors have read and agreed to the published version of the manuscript.

Funding: The APC was funded by Researchers Supporting Project No. (RSP-2021/138) King Saud University, Riyadh, Saudi Arabia.

Institutional Review Board Statement: Not applicable.

Informed Consent Statement: Not applicable.

Data Availability Statement: Not applicable.

Acknowledgments: The authors would like to thank the Researchers Supporting Project No. (RSP2021/138) King Saud University, Riyadh, Saudi Arabia for funding this project.

Conflicts of Interest: The authors declare no conflict of interest. 


\section{References}

1. Arora, S.; Prasad, R. An overview of dry reforming of methane: Strategies to reduce carbonaceous deactivation of catalysts. RSC Adv. 2016, 6, 108668-108688. [CrossRef]

2. Li, M.; Sun, Z.; Hu, Y.H. Catalysts for $\mathrm{CO}_{2}$ reforming of $\mathrm{CH}_{4}$ : A review. J. Mater. Chem. A 2021, 9, 12495-12520. [CrossRef]

3. Bao, Z.; Yu, F. Catalytic Conversion of Biogas to Syngas via Dry Reforming Process. In Advances in Bioenergy; Li, Y., Ge, S., Eds.; Elsevier: Amsterdam, The Netherlands, 2018; Volume 3, pp. 43-76.

4. Wang, X.; Economides, M. Advanced Natural Gas Engineering, 1st ed.; Elsevier: Amsterdam, The Netherlands, 2009 ; pp. 1-368.

5. Daza, C.E.; Gallego, J.; Mondragon, F.; Moreno, S.; Molina, R. High stability of Ce-promoted Ni/Mg-Al catalysts derived from hydrotalcites in dry reforming of methane. Fuel 2010, 89, 592-603. [CrossRef]

6. Jeong, D.W.; Jang, W.J.; Shim, J.O.; Roh, H.S.; Son, I.H.; Lee, S.J. The effect of preparation method on the catalytic performance over superior $\mathrm{MgO}$-promoted $\mathrm{Ni}-\mathrm{Ce}_{0.8} \mathrm{Zr}_{0.2} \mathrm{O}_{2}$ catalyst for $\mathrm{CO}_{2}$ reforming of $\mathrm{CH}_{4}$. Int. J. Hydrogen Energy 2013, 38, 13649-13654 [CrossRef]

7. Son, I.H.; Lee, S.J.; Song, I.Y.; Jeon, W.S.; Jung, I.; Yun, D.J.; Jeong, D.W.; Shim, J.O.; Jang, W.J.; Roh, H.S. Study on coke formation over $\mathrm{Ni} / \gamma-\mathrm{Al}_{2} \mathrm{O}_{3}, \mathrm{Co}-\mathrm{Ni} / \gamma-\mathrm{Al}_{2} \mathrm{O}_{3}$, and $\mathrm{Mg}-\mathrm{Co}-\mathrm{Ni} / \gamma-\mathrm{Al}_{2} \mathrm{O}_{3}$ catalysts for carbon dioxide reforming of methane. Fuel 2014, 136, 194-200. [CrossRef]

8. Quiroga, M.M.B.; Luna, A.E.C. Catalytic activity and effect of modifiers on Ni-based catalysts for the dry reforming of methane. Int. J. Hydrogen Energy 2010, 35, 6052-6056. [CrossRef]

9. Khan, A.; Sukonket, T.; Saha, B.; Idem, R. Catalytic activity of various $5 \mathrm{wt} . \% \mathrm{Ni} / \mathrm{Ce}_{0.5} \mathrm{Zr}_{0.33} \mathrm{M}_{0.17} \mathrm{O}_{2-\delta}$ catalysts for the $\mathrm{CO}$ reforming of $\mathrm{CH}_{4}$ in the presence and absence of steam. Energy Fuels 2012, 26, 365-379. [CrossRef]

10. Chen, H.W.; Wang, C.Y.; Yu, C.H.; Tseng, L.T.; Liao, P.H. Carbon dioxide reforming of methane reaction catalyzed by stable nickel copper catalysts. Catal. Today 2004, 97, 173-180. [CrossRef]

11. Pompeo, F.; Nichio, N.N.; Ferretti, O.A.; Resasco, D. Study of Ni catalysts on different supports to obtain synthesis gas. Int. J. Hydrogen Energy 2005, 30, 1399-1405. [CrossRef]

12. Damyanova, S.; Pawelec, B.; Arishtirova, K.; Fierro, J.L.G. Ni-based catalysts for reforming of methane with $\mathrm{CO}_{2}$. Int. J. Hydrogen Energy 2012, 37, 15966-15975. [CrossRef]

13. $\mathrm{Hu}$, Y.H.; Ruckenstein, E. Catalytic conversion of methane to synthesis gas by partial oxidation and $\mathrm{CO}_{2}$ reforming. Adv. Catal 2004, 48, 297-345.

14. Luengnaruemitchai, A.; Kaengsilalai, A. Activity of different zeolite-supported Ni catalysts for methane reforming with carbon dioxide. Chem. Eng. J. 2008, 144, 96-102. [CrossRef]

15. Flanigen, E.M.; Jansen, J.; Bekkum, H.V. Introduction to Zeolite Science and Practice, 2nd ed.; Elsevier: Amsterdam, The Netherlands, 1991; pp. 1-1078.

16. Csicsery, S.M. Shape-selective catalysis in zeolites. Zeolites 1984, 4, 202-213. [CrossRef]

17. Khouw, C.B.; Dartt, C.B.; Labinger, J.A.; Davis, M.E. Studies on the Catalytic-Oxidation of Alkanes and Alkenes by Titanium Silicates. J. Catal. 1994, 149, 195-205. [CrossRef]

18. Kareem, A.; Chand, S.; Mishra, I. Disproportionation of Toluene to Produce Benzene and p-Xylene: A Review. J. Sci. Ind. Res. 2001, 60, 319-327.

19. Marcilly, C.R. Where and how shape selectivity of molecular sieves operates in refining and petrochemistry catalytic processes. Top. Catal. 2000, 13, 357-366. [CrossRef]

20. Weitkamp, J. Zeolites and catalysis. Solid State Ion. 2000, 131, 175-188. [CrossRef]

21. Nimwattanakul, W.; Luengnaruemitchai, A.; Jitkarnka, S. Potential of Ni supported on clinoptilolite catalysts for carbon dioxide reforming of methane. Int. J. Hydrogen Energy 2006, 31, 93-100. [CrossRef]

22. Wang, K.; Li, X.; Ji, S.; Sun, S.; Ding, D.; Li, C. CO 2 reforming of methane to syngas over Ni/SBA-15/FeCrAl. Stud. Surf. Sci. Catal. 2007, 167, 367-372.

23. Wei, B.; Yang, H.; Hu, H.; Wang, D.; Jin, L. Enhanced production of light tar from integrated process of in-situ catalytic upgrading lignite tar and methane dry reforming over Ni/mesoporous Y. Fuel 2020, 279, 118533. [CrossRef]

24. Albarazi, A.; Beaunier, P.; Da Costa, P. Hydrogen and syngas production by methane dry reforming on SBA-15 supported nickel catalysts: On the effect of promotion by $\mathrm{Ce}_{0.75} \mathrm{ZrO}_{0.25} \mathrm{O}_{2}$ mixed oxide. Int. J. Hydrogen Energy 2013, 38, 127-139. [CrossRef]

25. Vafaeian, Y.; Haghighi, M.; Aghamohammadi, S. Ultrasound assisted dispersion of different amount of Ni over ZSM-5 used as nanostructured catalyst for hydrogen production via $\mathrm{CO}_{2}$ reforming of methane. Energy Convers. Manag. 2013, 76, 1093-1103. [CrossRef]

26. Bawah, A.-R.; Malaibari, Z.O.; Muraza, O. Syngas production from $\mathrm{CO}_{2}$ reforming of methane over Ni supported on hierarchical silicalite-1 fabricated by microwave-assisted hydrothermal synthesis. Int. J. Hydrogen Energy 2018, 43, 13177-13189. [CrossRef]

27. Dai, C.; Zhang, S.; Zhang, A.; Song, C.; Shi, C.; Guo, X. Hollow zeolite encapsulated Ni-Pt bimetals for sintering and coking resistant dry reforming of methane. J. Mater. Chem. 2015, 3, 16461-16468. [CrossRef]

28. Estephane, J.; Aouad, S.; Hany, S.; Khoury, B.E.; Gennequin, C.; Zakhem, H.E.; Nakat, J.E.; Aboukais, A.; Aad, E.A. CO 2 reforming of methane over Ni-Co/ZSM5 catalysts. Aging and carbon deposition study. Int. J. Hydrogen Energy 2015, 40, 9201-9208. [CrossRef]

29. Hambali, H.U.; Jalil, A.A.; Abdulrasheed, A.A.; Siang, T.J.; Vo, D.V.N. Enhanced dry reforming of methane over mesostructured fibrous Ni/MFI zeolite: Influence of preparation methods. J. Energy Inst. 2020, 93, 1535-1543. [CrossRef] 
30. Ibrahim, A.A.; Fakeeha, A.H.; Fatesh, A.S.A. Enhancing hydrogen production by dry reforming process with strontium promoter. Int. J. Hydrogen Energy 2014, 39, 1680-1687. [CrossRef]

31. Fatesh, A.S.A.; Ibrahim, A.A.; Fakeeha, A.H.; Soliman, M.A.; Siddiqui, M.R.; Abasaeed, A.E. Coke formation during $\mathrm{CO}_{2}$ reforming of $\mathrm{CH}_{4}$ over alumina-supported nickel catalysts. Appl. Catal. A Gen. 2009, 364, 150-155. [CrossRef]

32. Sarkar, B.; Tiwari, R.; Singha, R.K.; Suman, S.; Ghosh, S.; Acharyya, S.S.; Mantri, K.; Konathala, L.N.S.; Pendem, C.; Bal, R. Reforming of methane with $\mathrm{CO}_{2}$ over Ni nanoparticle supported on mesoporous ZSM-5. Catal. Today 2012, 198, 209-214. [CrossRef]

33. Fakeeha, A.H.; Naeem, M.A.; Khan, W.U.; Fatesh, A.S.A. Syngas production via $\mathrm{CO}_{2}$ reforming of methane using Co-Sr-Al catalyst. J. Ind. Eng. Chem. 2014, 20, 549-557. [CrossRef]

34. Naeem, M.A.; Fatesh, A.S.A.; Abasaeed, A.E.; Fakeeha, A.H. Activities of Ni-based nano catalysts for $\mathrm{CO}_{2}-\mathrm{CH}_{4}$ reforming prepared by polyol process. Fuel Process. Technol. 2014, 122, 141-152. [CrossRef]

35. Fatesh, A.S.A.; Atia, H.; Dahrieh, J.K.A.; Ibrahim, A.A.; Eckelt, R.; Armbruster, U.; Abasaeed, A.E.; Fakeeha, A.H. Hydrogen production from $\mathrm{CH}_{4}$ dry reforming over Sc promoted Ni/MCM-41. Int. J. Hydrogen Energy 2019, 44, 20770-20781. [CrossRef]

36. Laosiripojana, N.; Sutthisripok, W.; Assabumrungrat, S. Synthesis gas production from dry reforming of methane over $\mathrm{CeO}_{2}$ doped $\mathrm{Ni} / \mathrm{Al}_{2} \mathrm{O}_{3}$ : Influence of the doping ceria on the resistance toward carbon formation. Chem. Eng. J. 2005, 112, 13-22. [CrossRef]

37. de Sousa, F.F.D.; de Sousa, H.S.A.; Oliveira, A.C.; Junior, M.C.C.; Ayala, A.P.; Barros, E.B.; Viana, B.C.; Filho, J.M.; Oliveira, A.C. Nanostructured Ni-containing spinel oxides for the dry reforming of methane: Effect of the presence of cobalt and nickel on the deactivation behaviour of catalysts. Int. J. Hydrogen Energy 2012, 37, 3201-3212. [CrossRef]

38. Moradi, G.; Khezeli, F.; Hemmati, H. Syngas production with dry reforming of methane over Ni/ZSM-5 catalysts. J. Nat. Gas Sci. Eng. 2016, 33, 657-665. [CrossRef]

39. Najfach, A.J.; Almquist, C.B.; Edelmann, R.E. Effect of Manganese and zeolite composition on zeolite-supported Ni-catalysts for dry reforming of methane. Catal. Today 2021, 369, 41-47. [CrossRef]

40. Al-Fatesh, A.S.; Arafat, Y.; Atia, H.; Ibrahim, A.A.; Ha, Q.L.M.; Schneider, M.; M-Pohl, M.; Fakeeha, A.H. CO $\mathrm{CO}_{2}$-reforming of methane to produce syngas over Co-Ni/SBA-15 catalyst: Effect of support modifiers $(\mathrm{Mg}$, $\mathrm{La}$ and $\mathrm{Sc})$ on catalytic stability. J. $\mathrm{CO}_{2}$ Util. 2017, 21, 395-404. [CrossRef] 